\title{
(Re)discovering Pedagogy of the Oppressed
}

\author{
Christopher Darius Stonebanks
}

\begin{abstract}
This article chronicles a crisis of alignment regarding Critical Pedagogy due to the top-down power structures of White authority that is pervasive in the theory's North American academic environment. Contesting the often touted "radical" or "revolutionary" nature of Critical Pedagogy in higher education spaces, the author questions his relationship with Paulo Freire's work, Pedagogy of the Oppressed, ultimately abandoning the content of writing over the way the theory/philosophy is lived in academia. Through the lived experience of engaging with community in the James Bay Cree territories and Malawi, the question is asked as to who owns Freire's rebellious call to action.
\end{abstract}

\section{Prologue}

It's hard to start this article. Even though it's not a face-to-face conversation, it's still hard. I won't be able to track the real reaction on your face and the furrows in your brow as you take in what I'm about to say. I don't know if this is easier or harder for you but I am past caring about making it easier; it has to happen so let's begin. We need to talk about race in punk... like now. (Phillips, 2013, para. 1 \& 2)

This article will not be about punk music, although I could have written about punk music and simply done a "search and replace," inserting Critical Pedagogy in its place. Punk music's use is to show that movements that self-proclaim a set of convictions and values, are often not lived out. As one of the very few non-Christian, Middle Eastern immigrants to the west end suburbs of Montreal, Canada, punk music had a great allure to me in the 1980s, as it represented something I could potentially belong to, in the face of feeling so desperately outside of the seemingly homogenous community in which we lived. Punk stood against sameness, against the consumerism of suburbia, and against normative status-quo social practices, or at least that is what I read into the music and proclaimed texts on the back of album covers. However, living the punk experience was somewhat different than what the music, or the revolutionary message screamed. Punk music, and the actual focus of this paper, Critical Pedagogy, has a liberation edge that declares a "speak truth to power" philosophy. Punk and Critical Pedagogy share the same "we are dangerous, and the status quo doesn't like what we have to say" declarations. However, Kai (2014) asks an important question about an artistic genre asserting to be the definitive voice for resistance against conventional politics, society, and norms, "If punk is the ultimate anti-establishment scene, why is it still run by all these white men?" (para. 1). The same question needed to be asked about Critical Pedagogy.

Writing this chapter on the "race problem" in critical pedagogy makes me nervous because I fear what might happen when powerful critical pedagogy figures read it. As an assistant professor soon to be going up for tenure, I understand the importance of having influential allies; being a radical in academia can be very tricky business. (Allen, 2006, p. 3) 
In Reinventing Critical Pedagogy (Rossatto et al., 2006), Allen's chapter, "The Race Problem in the Critical Pedagogy Community," confronts the elephant in the room regarding racism within Critical Pedagogy: that is the fear and nervousness in calling out a hierarchical structure infused with White privilege (Diangelo, 2018; Eddo-Lodge, 2018; hooks, 1994). What can be said about a radical, grassroots, and revolutionary ideology, when speaking truth to its establishment after the death of its founders-namely its post-Freire leaders and academic "rock stars" —other than there is danger involved?

The first few drafts of this article began in 2013 as a breakup letter to Paulo Freire and his creation of Critical Pedagogy. Reading Stephanie Phillips' blog about the realities of racism she encountered as a Black woman within the punk rock scene was the final push for me to "unfriend" with Freire, to "dump" Paulo, to "ghost" his writing, and ignore his friend circle in all the places we used to hang out. I had to leave him, because although we needed to talk about racism in Critical Pedagogy . . . like now, we were not allowed to have that conversation. The humanizing and liberatory aspects that made up Freire's work were not being lived out, and I began to loathe him for it.

This article is about a crisis of philosophical alignment that first recognized, in retrospect, a Freirean approach to teaching and learning in the James Bay Cree community of Mistissini, then, when encountered with the followers of Critical Pedagogy, drove the author to depart from the theory, only to (re)discover Paulo Freire's philosophical intent, relevance, importance, and application in the rural region of Malawi. At the outset, it needs to be stated that this is not a parallel to the religious "footprints in the sand" poem, where I realized Freire was carrying me when it was most needed. Far from it. This article is more attune to Eddo-Lodge's (2018) miscomprehended "break-up letter" with White people regarding the discussion of race. The purpose of this article is not to analyze the comparative issues regarding problems with punk music to critical pedagogy as it relates to racism (although, that would be useful), or to fully examine the very real problems of ethics of implementation that Critical Pedagogy has in the Global North in regard to reinforcing White privilege (more needs to be done on this). Rather, its central aim is to illustrate that the foundational writing of Freire's Pedagogy of the Oppressed (2018), originally published in Portuguese in 1968 and translated into English in 1970, has a tremendous amount to offer classrooms, locally and globally, and needs to escape the hierarchies that have been wound into the White status quo of the Global North (in this article, focusing on Canada and the United States), to return to its emancipatory, liberation, and humanization roots. I hope to do this by illustrating the use of Freire's Pedagogy of the Oppressed in the concrete development of a public campus, owned by a local community and dedicated to lifelong learning in the rural region of Kasungu, Malawi. Malawi being one of the most impoverished countries in the world. In effect, this article is about living many of the ideals put forward by Freire. 


\section{First Meeting}

I first met Freire's work like many students of Education do, in an undergraduate class under the course umbrella of philosophy and/or sociology. In a Sociology of Education class, sometime in the late 1980s, my professor introduced us to the three primary schools of thought that influenced schooling at the time, Critical Theory, Functionalism, and Symbolic Interactionism. Paulo Freire's work came under Critical Theory, and given my perfecto leather jacket, ripped jeans, and Doc Martins, the engaged and observant professor believed that this was the theory for me. Marxism, revolution, defying top-down systems, "stick it to the man," everything my pinback buttons screamed, seemed to clearly connect with these ideals. However, I came into Education because I hated schools due to the racism my siblings and I encountered on a daily basis (Stonebanks, 2004). Symbolic Interactionism, and Charles Horton Cooley in particular through the "looking glass self," had a profound impact on the way I understood identity formation vis-à-vis perceptions of dehumanization imposed on racialized others. Life and the Student: Roadside Notes on Human Nature, Society and Letters (Cooley, 1927) was both the focus of my Masters' thesis, and the only original edition book I have ever sought and purchased. When we had to do an end-of-year oral presentation on a specific theory that spoke to us, my undergraduate professor asked about my certainty regarding Cooley's work. After all, the assignment connected to a critical incident we completed at the beginning of the course, and I had written about one of the many violent encounters in school during childhood. Given the nature of the critical encounter, the professor suggested that Freire's work may have more meaning and may be better suited to answer fundamental questions. But, I was resolute; it was Cooley for me, not Freire. But, in an effort to show that I had done due diligence, I purchased a copy of Pedagogy of the Oppressed, leafed through it, maybe (maybe) underlined some passages (doubtful), and had it on my desk in class to make sure the illusion was created that I had made an informed decision.

By 1995, I had graduated with my Masters of Arts in Educational Studies, and through complete chance found myself teaching for Collège d'enseignement général et professionnel (CEGEP) St. Felicien in the James Bay Cree community of Mistissini, in a program titled "Native Early Childhood Education" (NECE). At the time, the location was termed by the CEGEP as "isolated," but the community and its people were not. Working with adult women, the majority of whom were older, mothers, wiser, more patient, and residential school survivors, was one of the most enriching experiences of my life. The position came with (at best) loose physical or academic support, and there was no administration lording over you. In the early days, before Quebec's official curriculum became competency based (Ministère de l'Éducation, 2001), the instructors in each of the nine James Bay Cree villages were given competency-based outcomes, and wide liberties on how to achieve them. No standardized curriculum, no set textbooks, no predetermined teaching resources, no end-of-term standard tests, and in some cases, no classroom. There I was, with a group of adults, barely an adult myself and tasked to have them certified to be daycare teachers within two years. Moreover, experiences of residential schooling and colonialism loomed large in the face of considering what it meant to be a "certified" preschool and daycare teacher in a Cree community. 
Authentic liberation-the process of humanization-is not another deposit to be made in men. Liberation is a praxis: the action and reflection of men and women upon their world in order to transform it. Those truly committed to the cause of liberation can accept neither the mechanistic concept of consciousness as an empty vessel to be filled, nor the use of banking methods-of domination (propaganda, slogans-deposits) in the name of liberation. (Freire, 2018, p. 79)

In Mistissini, I had no reference books to draw from. I certainly did not have my copy of Pedagogy of the Oppressed. Nor can I recall any strong memories of Freire either. What was clear, was that with little of the typical resources available to a neophyte CEGEP instructor, that any kind of meaningful teaching and learning experience was not going to come from a manual, guide, or textbook. Somehow, we made the choice, that the standard roles of "teacher" and "student" had to be reimagined. Without referring to Freire (2018) in any way, we concluded that, "(a)t the point of encounter there are neither utter ignoramuses nor perfect sages; there are only people who are attempting, together, to learn more than they now know" (p. 90). As a young man, with a young wife, and an infant daughter, I was very aware that the women I worked with were organized and purposeful in their support and defense of the NECE program and the new human beings who entered into their community. Freire writes that, "(d)ialogue cannot exist, however, in the absence of a profound love for the world and for the people" (p. 89). Heavily influenced by Freire, bell hooks' Teaching to Transgress: Education as the Practice of Freedom (1994) spoke on, among many topics, love, classroom as a community and a co-constructed curriculum with students. Love certainly played a role in how we quickly grew to communicate with each other in our class, and soon we were collectively looking at expected competency attainments and considering locally relevant ways to achieve goals. In a class of 13 adult students, all input was key and the coursework became richer and more rewarding for their individual contributions. On moving away from traditional top-down pedagogy, hooks writes, "( $\mathrm{t}$ )he exciting aspect of creating a classroom community where there is respect for individual voices is that there is infinitely more feedback because students do feel free to talk-and talk back. And, yes, often this feedback is critical" (p. 42). That relationship of a negotiated classroom space built on ethics of love, respect, and care became a cornerstone of my experience in Mistissini. Sure, when the students graduated, the class valedictorian cried and said that no one ever pushed them harder than I did, but it was a speech filled with pride for the group as a whole, and I responded on stage telling them that no one had pushed me harder than they did. My time as a teacher in Mistissini ended up being a large part of my 2005 PhD dissertation, and then a few years later, reworked, as a book, James Bay Cree and Higher Education (2008). In the rewrite, Freire's work became more prominent upon personal reflection and public deliberation.

\section{Commitment}

In a post 9/11, US Patriot Act and "war on terror" world, Canada saw some of these White Critical Pedagogy rock stars arrive at our universities, hoping for new a space of academic freedom, which was seen as increasingly under threat in the USA. Many of these rock stars brought genuine mentorship, publication opportunities and, unwittingly or not, a distinct culture surrounding what it meant to belong to a group that followed a theory. I had one of these rock stars as part of my dissertation review committee, and he was a wonderful supporter. This rock star took a great interest in my work history in the Cree 
community of Mistissini, especially as it related to aspects of demonstrable implementations of Critical Pedagogy. The lack of standardized texts, and other materials, fascinated him. He would question, "How did we come up with teaching and learning strategies that were so Freirean?" Was there anything I remembered, in detail, that perhaps influenced classroom approaches? In truth, there was a vivid memory in my Masters' program at Concordia University, where a professor started a lecture by writing Praxis on the blackboard in bold, white chalk. "Liberation is a praxis: the action and reflection of men and women upon their world in order to transform it" (Freire, 2018, p. 79). Praxis was introduced in that Masters' class as "putting theory into action." The challenge was put clearly: All these lofty ideas about equality and equity we talk about in departments of education and universities, can they be put into practice in actual classrooms? With absolute certainty, the process of reflection and action on the world was put into practice in Mistissini to develop an interactive, community-based classroom approach. But what about another one of Freire's contributions to education, his anti-banking contributions? A banking approach, the traditional method of teaching is described by Freire as the following:

(a) the teacher teaches and the students are taught;

(b) the teacher knows everything and the students know nothing;

(c) the teacher thinks and the students are thought about;

(d) the teacher talks and the students listen-meekly;

(e) the teacher disciplines and the students are disciplined;

(f) the teacher chooses and enforces his choice, and the students comply;

(g) the teacher acts and the students have the illusion of acting through the action of the teacher;

(h) the teacher chooses the program content, and the students

(who were not consulted) adapt to it;

(i) the teacher confuses the authority of knowledge with his or

her own professional authority, which she and he sets in opposition to the freedom of the students;

(j) the teacher is the Subject of the learning process, while the pupils are mere objects. (p. 73)

In this method, the reality of the authority, the teacher (oppressor) is forced upon the subject, the student (oppressed). Whether through a hidden memory of Freire, intuition or "teacher survival mode," this is certainly not how I approached the classroom. Dialogue was key to each day, and we moved forward together with a communal approach to better understanding and acting on our tasks and world through reflection. Perhaps this rock star was right, and I began to read and reread Pedagogy of the Oppressed. At this point in my life I called myself a Critical pedagogue, continuing my teaching approach at the university level, but now grounding what I had already started through a theory.

During this time, many of these rock stars were intent on demonstrating that Critical Pedagogy was being put into practice to the benefit of human beings, especially those in greatest need. The rock star with whom I was working was determined to find examples of enacting innovative Critical Pedagogy spaces, not reporting on it after the fact. This became a key conversation with him, as we discussed potential classroom teachers who had expressed significant interests to Freirean ideals in graduate classes who could be observed and supported in their radical teaching. Unfortunately, this never really came to pass, 
as finding those concrete examples in public schooling proved more of a challenge than anticipated. Yes, there were many examples of wonderful teachers doing wonderful things, but a revolution leading to something like racial equity really did not seem to be part of the lesson plan. Meanwhile, many of us neophyte academics found ourselves caught in the nervousness that Allen (2006) describes all too well, focusing on allegiances and their connections to publication opportunities over anything truly grassroots and racially emancipatory. Over time the environment, or the culture of Critical Pedagogy, became inauthentic, in the gentlest of descriptors. Those of us in early stages of our careers who were vying for spaces in an institution that had been referred to as sociopathic (Gatto, 2017), contributed in our own way to propping up a system of White status quo, conformity, and top-down directives. Mocking the hypocrisy of the mid 1980s efforts of US rock stars raising money for starving children in "Africa," Joey Ramone, lead singer of the punk band, The Ramones, said, "If you're not in it, you're out of it." I started to see holes in the lived realities of those that espoused Critical Pedagogy, and I was starting to feel out of it.

\section{Growing Apart}

In my experience, to be a part of the punk scene meant, at most, being part of its peripheral edges and acceptance in knowing your place. Racism did (and for all I know, still does) exist in the punk scene. However, punk, as a cultural phenomenon, appears to be owning this reality better than Critical Pedagogy. A Google search on, in quotes, "racism in punk" results in over 2,500 hits, with musicians like Phillips imploring that the race problem needs to be addressed. On the other hand, if we examine another self-asserting vanguard of anti-racism, like critical pedagogy, only one result is listed, that being Rossatto and colleagues' (2006) Reinventing Critical Pedagogy. Curiously similar to Phillips' sentiment of the conversation being hard to start, in Allen's chapter he writes of being "nervous" (p. 3) about discussing the race problem in the critical pedagogy community, and he also notes that he is "... going to say it anyway" (p. 4). In the same spirit of Phillips and Allen, I will have that difficult conversation, too.

Freire's work covers such noble pursuits, such as anti-banking models of teaching and learning, emancipatory and liberation pedagogy, revealing dehumanization and collectively pursuing humanization, dialogical pedagogy, critical thinking, critical literacy, and critical consciousness raising. The focus of these pursuits is in the very title of his most influential book: Pedagogy of the Oppressed. In her dialogue with herself about Freire, hooks (1994) spoke about the sexism in his work and noted, "Freire's own model of critical pedagogy invites a critical interrogation of this flaw in the work" (p. 49). Had I read hooks with the attention it deserved, perhaps I could have also had a playful dialogue with Freire regarding the complete absence of BIPOC leaders within the Critical Pedagogy hierarchy.

There was an envy amongst many in the Critical Pedagogy circles, in particular, that a Muslim heritage and brown skin were a real boon for someone's academic advancement. How lucky we all were to have narratives of oppression and marginalization. Suddenly there was a pay-off for being perceived as an Ay-rab, a Paki, an eye-ranian, or simply a terrorist. Suddenly there was a pay-off for the slashed tires, arson attempts, verbal abuse, physical abuse and an array of other hostility in both youth and adulthood. 9/11, for those that did not recognize the racism to Muslims and peoples of the Middle East that existed 
prior to this date, was a godsend to our publication careers. But to get career advancement in academia amongst so many of the Critical Pedagogy elite, you had to toe-the-line. You had to receive the approval to speak from those who explicitly stated that they were ahead of you on the academic ladder. Deference had to be paid, and if so, you were allowed a voice. If you step out of line, if you dare to say the emperor or empress is not wearing any clothes, you run the very real risk of being the one publicly stripped. None of this made sense for a theory that was supposed to be about humanization and liberation. The way it was being lived had nothing to do with these ideals. Critical Pedagogy seemed like a White-controlled space that made personal profit from the Black, Indigenous, and People of Colour (BIPOC) community. So, I drifted away from Paulo.

\section{Separation}

Late 2008, an idea for university students "re-engaging" with the Global South (GS) was forwarded by an administrator. In particular, it was a country in east sub-Sahara that was the destination to assist the administrator's friend on an existing effort in its early stages of development. It was a typical idea forwarded by a university executive, in that it was heavy on promotion of the home institution, light on GS community benefits (beyond time with White students), and completely void of financial support. It was "volun-tourism," "exposure-tourism," and Peace Corps fantasies (Geidel, 2015) revisited, of the first world saving the third world by simply being present. Despite my concerns, I did think GN students benefitted from cross-cultural exchanges, and chance played a role in the decision to go to the region, fuelled by a colleague's own project in the central, rural region of Malawi (neighbouring the original country of destination). As well, I had a growing concern that my academic epitaph would read, "He worked in elementary schools for around 10 years and then taught college in the James Bay Cree area ... then he talked about that a lot in his classes." Despite promotion of the other sub-Saharan country, Malawi was picked as a start for initial discussions regarding any potential university community endeavours. Although conversations with diverse communities played a large part in decision making regarding location, the realities of Malawi were patently significant. Malawi is a landlocked country in the sub-Sahara that is referred to globally as "... one of the poorest ... in the world" (International Monetary Fund, 2017, p. 4), is ranked 174th out of 187 in terms of poorest and least developed (UNDP, 2014, p. 162), and the United Nations describes it in terms of being impoverished (Gwede, 2015). If anyone has romantic ideas of local contentment in opposition to these poverty definers, local rural Malawians shatter this illusion when they self-identify as "... very poor" (Stonebanks, 2008, p. 389; Emory, 2015, p. 10), with academics equally echoing the people's state of living (Miller et al., 2010; Chowns, 2015; Mchenga et al., 2017; Kretzer et al., 2017). With extreme economic poverty, education (Durston \& Nashire, 2001; Roche, 2016) and healthcare (Makwero, 2018; Makaula et al., 2019) sectors (despite best efforts) are overwhelmed and unable to provide basic services to a population of 19 million.

Initial meetings with around 10 villages commenced with village elders and a variety of representatives (youth, professionals, etc.) attending sessions to discuss what their thoughts were about community-university partnerships (Stonebanks, 2014). Much of the early talk focused on optimism, while balanced with the kind of reality of foreign efforts described (Katz, 2013) as new, big, clean, white trucks simply "driving by" 
on the highway to somewhere else. Malawi was (and still is) littered with dilapidated and abandoned buildings that represent foreign agencies' efforts of good intentions (Easterly, 2006; Barry-Shaw et al., 2012), all partially standing to remind us of how easy it is to fail in these efforts. Considerations on "needs" was daunting, and the first few years were based on Malawian participants insisting that Canada (as if we represented a nation) bring solutions to evident community problems. Health, Education, and Development were all listed by community as immediate needs of improvement, and the clarity from local participants that "we" had something to teach "them" that would alleviate suffering. Having put aside Freire, I was bringing to the conversation the likes of Fanon (2004), Illitch (1968), and Moyo and Ferguson (2010), who all seemed to be imploring that the best way to approach this was to simply leave. In response, local community took this as pessimism and responded with fulfilling immediate needs with a banking style of restoration. Frustrated with the idea that we were holding back on a secret to success held by the GN, at a certain point I even offered to commit to the personal cost of going to Malawi, around \$5000 Canadian, for a span of 10 years, if we stopped coming and they made local decisions on how to best use funds. The offer was rejected. Just like with my relationship with Freire, community and I were at an impasse.

\section{Reconciliation}

Giroux (2010) writes that Critical Pedagogy is an "... educational movement, guided by passion and principle, to help students develop consciousness of freedom, recognize authoritarian tendencies, and connect knowledge to power and the ability to take constructive action" (para. 1). Passion, principle, freedom from oppression; these are admirable goals to do good. Often, the burden of being good comes with the responsibility of love. On love, Freire wrote "... love is an act of courage, not of fear, love is commitment to others. No matter where the oppressed are found, the act of love is a commitment to their cause - the cause of liberation" (p. 89). Rather than this kind of deep commitment to people, often the GN Critical Pedagogy culture would utilize a variance of "love" that is referred to as "radical love." It is, however, lived out more like a USA daytime talk show using "tough love," reducing love to a top-down mentality that does not veer significantly from the old White man's burden (Kipling, 1899) that is so often critiqued by the Critical Pedagogue. Care, which I believe must be a part of love, requires engrossment. Noddings (2003) writes, "(a)t the bottom, all caring involves engrossment. The engrossment need not be intense nor need it be pervasive in the life of the one caring, but it must occur" (p. 17).

Love, care, and engrossment are not techniques that can be imparted on a student or a process. Yet, it was a part of our collective success in Mistissini, and it was certainly what seemed to be missing in my short time trying to exist in GN academic Critical Pedagogy circles that were mired in the same top-down systemic racisms they would often rage against. On reflection of what came about naturally in Mistissini, I found the missing part to a difficult conversation in Malawi that was quickly taking us down a path of university travel-abroad fantasies, or abandonment. Freire (2018) wrote, "If I do not love the world-if I do not love life-if I do not love people-I cannot enter into dialogue" (p. 90). In one hand I held Fanon and, in the other, Freire; both offered excellent guidance. One a warning, and the other, hope. After many 
years of commitment to the cause, as a group we were able to agree that the answer to the problems of banking education could not be more banking education.

In sum: banking theory and practice, as immobilizing and fixating forces, fail to acknowledge men and women as historical beings; problem-posing theory and practice take the people's historicity as their starting point. (Freire, 2018, p. 84)

Examining historicity of both the local community and the way GN universities operated in Malawi, offering no more than short-term benefits, took time beyond the typical three-year research projections and required outputs by academia. Throughout Pedagogy of the Oppressed, Freire (2018) implores that authentic dialogue requires humility, faith, hope, and critical thinking (pp. 91-92). Establishing this trust eventually led to participants forwarding that existing structures related to Health, Education, and Development were lacking because Critical Thinking, Creativity, and Social Entrepreneurship had not been fostered or allowed under the colonial systems that required obedience and subservience. By 2014, five years into the dialogue, Chief Makupo, a college graduate himself, quietly pulled me aside and insisted that "games" needed to stop and that it was time to establish a centre, a physical centre, that was dedicated to the kinds of conversations we were having. A lifelong learning campus dedicated to Health, Education, and Development nurtured through Critical Thinking, Creativity, and Social Entrepreneurship. As a campus, the overarching theories and philosophies that drive our work are based on transformative learning (Mezirow, 1990), anti-banking pedagogy, liberation practices, critical consciousness raising (Freire, 2018), decolonizing viewpoints (Smith, 1999), and an action-oriented ethic of care (Noddings, 2003). Since that initial spark by Chief Makupo, and supported by Chief Chillonga, who dedicated one square mile of her traditional land, the Transformative Praxis Malawi campus now boasts a multipurpose community center, primary school, computer learning lab and an adult-ed classroom, experimental farming space, water borehole, living residence for research visitors, radio station, model toilets, a women's cooperative chicken coop, sports' field, and much more. The physical structures, all powered via solar energy, make up 40,000 $\mathrm{m}^{2}$. Employment, research, exploration of food security, taking risks on new curricula regarding permaculture-these are all concrete (often literal concrete) results that not many theories can bring into action.

The Learning Lab has copies of Pedagogy of the Oppressed, along with other readings that local members are free to peruse. The book does not exist as something to be worshipped, rather it stands as an important contributor to how the campus came to be and where it can go. Had I remained in the GN culture that had claimed Paulo Freire, I would never have realized that his work lived in places where people suffer from crippling oppression. It took me years to realize that GN ownership of Freire was as much a part of the kinds of systemic racism (Diangelo, 2018; Eddo-Lodge, 2018) that took possession of so much that surrounds us. In Malawi, like the James Bay Cree territories, Freire's work existed without a White filter. I grew to live with Freire by rejecting status-quo ownership and rejecting all of those that spoke on his behalf. One on one, I re-discovered a comrade. Albeit a comrade on paper. 


\section{Epilogue}

In the 50-year anniversary edition of Pedagogy of the Oppressed, Donaldo Macedo (2018) completely acknowledges that Freire was often criticized for not analyzing race relations, instead focusing on class oppression. Although it was something that he began to address before his death in 1997, I have no idea what he would make of the dominant White power structures that control his voice today in the GN. hooks (1994) quotes Freire, indicating his own uncertainty of his Whiteness, stating, "(a)s an apparent white man, because I always say that I am not quite sure of my whiteness ..." (p. 57). This uncertainty would have made for a fascinating dialogue, given his own criteria for how that would begin and develop. The Critical Pedagogy rock star, with whom I worked, expressed to me on many occasions that he worried about a predominantly White leadership. And he was right to have this concern, given the faces of its leaders.

In Norton's 2004 book, Leo Strauss and the Politics of American Empire, she notes that neo-conservatives "adore" Strauss, and that talk about him "... the way young girls talk about horses and boy bands," and that know trivialities about him, like his favourite movie was Zulu (p. 28). GN Critical Pedagogues are like that about Freire and his apparent apostles as well. It is all too much top-down fetishism and worship. Ultimately, Pedagogy of the Oppressed are words on a piece of paper whose ideas can be connected to the likes of Socrates (i.e., dialogue) and John Dewey (i.e., focus on the student's world). But they are good ideas that are well laid out and provide a powerful basis for action. I will never call myself a Critical Pedagogue, but I will insist that Pedagogy of the Oppressed is an essential reading to anyone who wants to act on oppression and live social justice ideals beyond platitudes.

Phillips (2013) concludes her discussion on racism and the existing White power structures in punk music by stating, "(m)y new band will exist, and we will be an all-black punk band" (para. 12). Shortly after she wrote her article, she did just that, creating Big Joanie, a black feminist punk band that still rocks today. Philips and her bandmates prove that no one owns revolutionary ideas, and if the so-called owners are not living the ideals they claim, well ... bullocks to those who cannot live these principles. Take the ideals back and turn them into action. Pedagogy of the Oppressed is yours to discover, or (re)discover and put into practice. Bullocks to them.

\section{References}

Allen, R. L. (2006). The race problem in the critical pedagogy community. In C. A. Rosatto, R. L. Allen, \& M. Pruyn (Eds.), Reinventing critical pedagogy. Brown \& Littlefield Publishers Inc.

Barry-Shaw, N., Jay, D., \& Engler, Y. (2012). Paved with good intentions: Canada's development NGOs from idealism to imperialism. Fernwood.

Chowns, E. (2015). Is community management an efficient and effective model of public service delivery? Lessons from the rural water supply sector in Malawi. Public Administration \& Development, 35(4), 263-276.

Cooley, C. H. (1927). Life and the student: Roadside notes on human nature, society and letters. Alfred Knopf Publisher. 
Diangelo, R. (2018). White Fragility: Why it's so hard for White people to talk about racism. Beacon Press.

Durston, S., \& Nashire, N. (2001). Rethinking poverty and education: An attempt by an education programme in Malawi to have an impact on poverty. Compare: A Journal of Comparative Education, $31(1), 75-91$.

Easterly, W. (2006). The white man's burden: Why the West's efforts to aid the rest have done so much ill and so little good. Penguin Press.

Eddo-Lodge, R. (2018). Why I am no longer talking to White People about Race. Bloomsburry Publishers.

Emory, D. (2015). Schools and the construction of identity and individuality: A comparative study between Malawi and Canada (Masters Thesis). McGill University Libraries.

Fanon, F. (2004). The wretched of the earth. Grove Press.

Freire, P. (2018). Pedagogy of the oppressed: 50th anniversary edition [Kindle Edition]. Bloomsburry Academic .

Gatto, J. (c2017). Dumbing us down: The hidden curriculum of compulsory schooling. New Society Publishers.

Geidel, M. (2015). Peace corps fantasies. University of Minnesota Press.

Giroux, H. A. (2010). Lessons from Paulo Freire. Chronicle of Higher Education, 57(9), B15-B16.

Gwede, W. (2015, February 26). UN places Malawi as impoverished nation: Minister takes spin on poorest status. http://www.nyasatimes.com/2015/02/26/un-places-malawi-as-impoverished-nationminister-takes-a-spin-on-poorest-status/

hooks, b. (1994). Teaching to transgress: Education as the practice of freedom. Routledge.

International Monetary Fund. (2017). Malawi: Economic Development Document. IMF. https://www.imf.org/ /media/Files/Publications/CR/2017/cr17184.ashx

Kai, A. (2014, November 9). If punk is the ultimate anti-establishment scene, why is it still run by all these white men? The Guardian. Retrieved from https://www.theguardian.com

Katz, J. M. (2013). The big truck that went by: How the world came to save Haiti and left behind a disaster. Palgrave Macmillan.

Kipling, R. (1899). The white man's burden: A poem. Doubleday and McClure Co.

Kretzer, M. M., Engler, S. G., \& Trost, E. (2017). Fighting resource scarcity - sustainability in the education system of Malawi - case study of Karonga, Mzimba and Nkhata Bay district. South African Geographical Journal, 99(3), 235-251.

Macedo, D. (2018). Introduction to the 50th anniversary edition. In P. Freire, Pedagogy of the oppressed. Bloomsbury Academic. 
Makaula, P., Funsanani, M., Mamba, K. C., Musaya, J., \& Bloch, P. (2019). Strengthening primary health care at district-level in Malawi - determining the coverage, costs and benefits of communitydirected interventions. BMC Health Services Research, 19(1), 509.

Makwero, M. T. (2018). Delivery of primary health care in Malawi. African Journal of Primary Health Care \& Family Medicine, 10(1), 1-3.

Mchenga, M., Chijere Chirwa, G., \& Chiwaula, L. S. (2017). Impoverishing effects of catastrophic health expenditures in Malawi. International Journal for Equity in Health, 16, 1-8.

Mezirow, J. (1990). Fostering critical reflection in adulthood: A guide to transformative and Emancipatory learning. Jossey-Bass Publishers.

Miller, C., Tsoka, M., Reichert, K., \& Hussaini, A. (2010). Interrupting the intergenerational cycle of poverty with the Malawi Social Cash Transfer. Vulnerable Children \& Youth Studies, 5(2), 108-121.

Ministère de l'Éducation, du Loisir et du Sport (2001). Quebec Education Program. Author. http://www.education.gouv.qc.ca/fileadmin/site_web/documents/education/jeunes/pfeq/PFEQ_ethiqueculture-religieuse-primaire_2008_EN.pdf

Moyo, D., \& Ferguson, N. (2010). Dead aid: Why aid is not working and how there is a better way for Africa (Reprint ed.). Farrar, Straus and Giroux.

Noddings, N. (2003). Caring: A relational approach to ethics and moral education. University of California Press.

Norton, A. (2004). Leo Strauss and the politics of American empire. Yale University Press.

Phillips, S. (2013, August 28). We Need to talk about Racism in Punk. Retrieved from Collapse Board: http://www.collapseboard.com/we-need-to-talk-about-racism-in-punk/

Roche, S. (2016). Education for all: Exploring the principle and process of inclusive education. International Review of Education, 62(2), 131-137.

Rosatto, C. A., Allen, R. L., \& Pruyn, M. (Eds.). (2006). Reinventing critical pedagogy.

Brown \& Littlefield Publishers Inc.

Smith, L. T. (1999). Decolonizing methodologies: Research and Indigenous peoples. Zed Books

Stonebanks, C. D. (2004). Consequences of perceived ethnic identities (reflection of an elementary school incident). In J. L. Steinberg (Ed.), The miseducation of the West: The hidden curriculum of Western-Muslim relations. Greenwood Press.

Stonebanks, C. D. (2008). James Bay Cree and higher education: Issues of identity and culture shock. Sense Publishing.

Stonebanks, C. D. (2014). Confronting old habits overseas: An analysis of reciprocity between Malawian stakeholders and a Canadian university. In N. D. Giardina (Ed.), Qualitative inquiry outside of the academia. Left Coast Press.

UNDP. (2014). Sustaining human progress: Reducing vulnerabilities and building resilience. Retrieved from Human development report: http://hdr.undp.org/sites/default/files/hdr14-report-en-1.pdf 


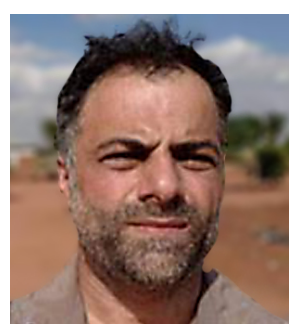

Christopher Darius Stonebanks is an award-winning Professor of Education at Bishop's and an Adjunct at McGill University. Among his life experiences are beginning his professional career in Teacher Education under the care of amazing students in the James Bay Cree territory, a personal understanding of the profound impact of imperialism and modern colonialism through the Iranian revolution, an ongoing familiarity with the cruel damage of being "the Other" in Canada and cocreating a lifelong learning campus in rural Malawi dedicated to decolonization and emancipation. 